Research Article

\title{
Numerical Simulation Research on Hydraulic Fracturing Promoting Coalbed Methane Extraction
}

\author{
Fan Yongpeng, ${ }^{1,2,3}$ Shu Longyong $\mathbb{D}^{2},{ }^{2}$ Huo Zhonggang, ${ }^{2}$ Hao Jinwei, ${ }^{2}$ and Yang $\mathrm{Li}^{2}$ \\ ${ }^{1}$ China Coal Research Institute, Beijing 100013, China \\ ${ }^{2}$ Mine Safety Technology Branch, China Coal Research Institute, Beijing 100013, China \\ ${ }^{3}$ College of Mining Engineering, Liaoning Technical University, Fuxin 123000, China \\ Correspondence should be addressed to Shu Longyong; slyccri@163.com
}

Received 9 June 2021; Accepted 5 July 2021; Published 14 July 2021

Academic Editor: Gan Feng

Copyright ( $\odot 2021$ Fan Yongpeng et al. This is an open access article distributed under the Creative Commons Attribution License, which permits unrestricted use, distribution, and reproduction in any medium, provided the original work is properly cited.

\begin{abstract}
Although hydraulic fracturing technology has been comprehensively investigated, few scholars have studied the influence of hydraulic fracturing on the effect of coalbed methane (CBM) extraction, and few considered the interaction between water and $\mathrm{CBM}$ in the research process, which is not conducive to guiding the engineering design of hydraulic fracturing wells. In this work, a hydraulic-mechanical-thermal coupled model for CBM extraction in hydraulic fracturing well is established; it combines gasliquid two-phase infiltration, where nonisothermal adsorption is also considered. The COMSOL Multiphysics software is used to carry out the numerical simulation study of the CBM extraction process in hydraulic fracturing well and analyze the influence of coalbed permeability, initial methane pressure, and fracture length on CBM extraction in hydraulic fracturing well, and the results show that the hydraulic-mechanical-thermal coupled model for CBM extraction can be used for CBM extraction research in hydraulic fracturing well. The initial coalbed permeability, initial gas pressure, and fracture length all affect the migration speed of CBM to surface well in different ways and have a greater impact on the CBM production rate of hydraulic fracturing well. The greater the initial coalbed permeability and methane pressure are, the longer the fracture length is and the greater the $\mathrm{CMB}$ production rate of hydraulic fracturing well is. The change trend of coalbed permeability during the extraction process of surface fracturing well is directly related to the state of the reservoir. The factors of stress, temperature, and CBM desorption jointly determine the increase or decrease of coal seam permeability.
\end{abstract}

\section{Introduction}

CBM is an associated gas of coal. Its calorific value is $1 \sim 4$ times that of general-purpose coal. With the rapid economic development and strong energy demand today, CBM development has become a hot issue [1]. China has the world's third largest CBM resources, but $75 \%$ of the CBM is in lowpermeability, soft, and deep-buried coal seams, which greatly increases the difficulty of CBM resource development [2]. In order to increase the production of CBM and promote the utilization of CBM resources, hydraulic fracturing technology is widely used in surface well CBM extraction projects $[3,4]$.

The principle of coalbed hydraulic fracturing technology is to inject high-pressure liquid into the original coalbed to promote the development of fractures and increase coalbed migration channels [5]. In 1947, the world's first fracturing well was completed in Hugoton Gas Field, Kansas, USA. With the rise of CBM development projects, it has been widely used in the field of CBM mining. In recent years, hydraulic fracturing wells have achieved widespread success in soft coalbed with low permeability. As of 2019, the CBM extraction volume of surface wells has reached 5.9 billion $\mathrm{m}^{3}$, most of which have adopted hydraulic fracturing technology.

Many scholars have done a lot of research on hydraulic fracturing technology: the authors of [6] analyzed the influencing factors of hydraulic fracturing on oil and gas production and proposed strategies to use the latest findings to enhance primary recovery and alleviate some 


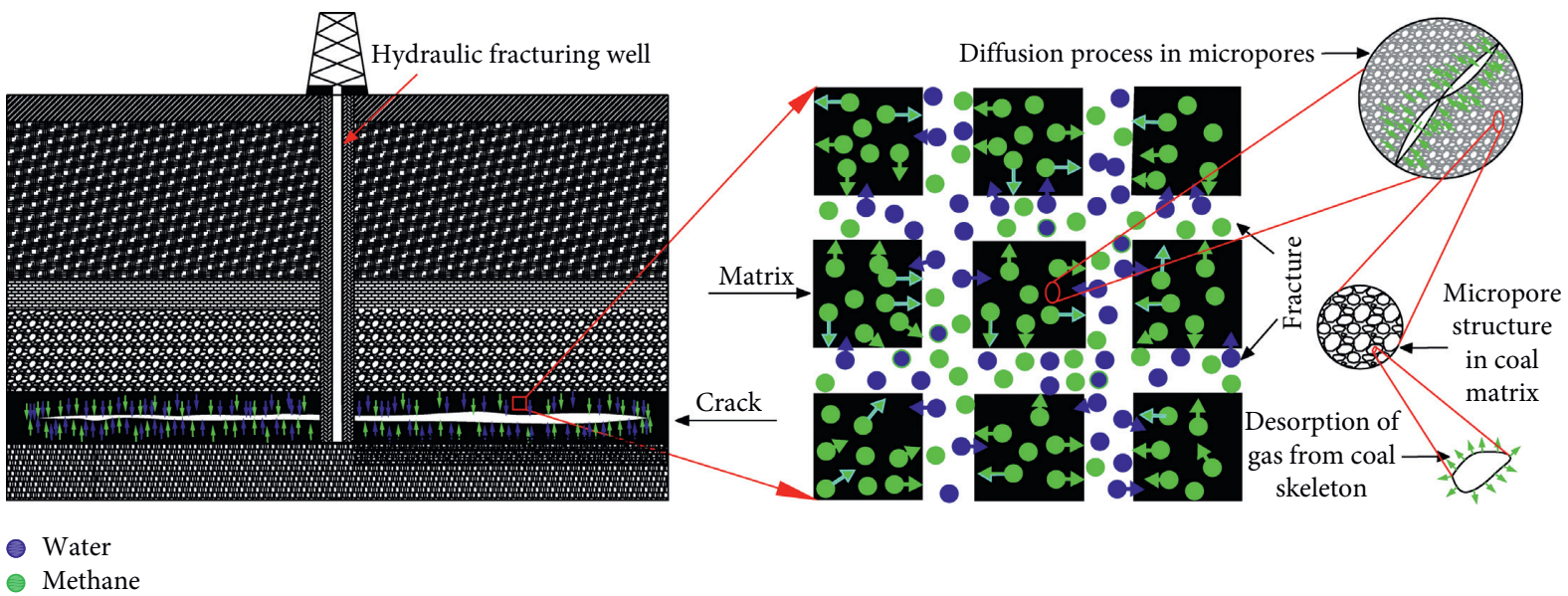

FIgURE 1: Schematic diagram of CBM exploitation process.

common problems in secondary recovery; the authors of [7] analyzed the influence of crustal stress field, confining pressure, and natural fractures on fractures in hydraulic fracturing wells by using similar laboratory tests; Zhang et al. [8] used a combination of hydraulic fracturing laboratory tests and three-dimensional scanning to analyze the influence of fracturing fluid injection pressure and velocity on the fracturing effect during the fracturing process; and Lei et al. [9] used true triaxial hydraulic fracturing physical simulation experimental equipment to analyze the influence of perforation on the direction of hydraulic pressure.

In terms of numerical simulation research of hydraulic fracturing, the author of [10] established a fully coupled elastic-plastic hydraulic fracturing model based on related theories of rock mechanics and fluid mechanics; the authors of [11] used numerical simulation method to study the characteristics of coal fracture development and propagation; the authors of [12] studied the influence of hydraulic fracturing on faults by numerical simulation; the authors of [5] analyzed the connection between macroscopic mechanical parameters and mesoscopic mechanical parameters based on two-dimensional particle flow code (PFC2D); the authors of [13] proposed a method to determine the maximum and minimum stresses and coal parameters of coalbed based on the pressure test values during hydraulic fracturing; and the authors of [14] established a thermohydromechanical coupled model to analyze the effects of coalbed permeability, gas pressure, temperature, and fracture radius on single-slit well gas drainage.

In this work, a hydraulic-mechanical-thermal coupled model for CBM extraction in hydraulic fracturing well is established; it combines gas-liquid two-phase infiltration, where nonisothermal adsorption is also considered. The COMSOL Multiphysics software is used to carry out the numerical simulation study of the CBM extraction process in hydraulic fracturing well and analyze the influence of coalbed permeability, initial pressure, and fracture length on CBM extraction in hydraulic fracturing well.

\section{The Hydraulic-Mechanical-Thermal Coupled Model for CBM Extraction in Hydraulic Fracturing Well}

CBM extraction will cause a series of changes in the coalbed. For example, CBM desorbs from the coal skeleton and migrates in the fissures, water seeps into the wellhead under the action of the pressure gradient, the coal body deforms, and the temperature exchanges (Figure 1). In order to establish a mathematical model describing the above process, the following hypotheses are proposed [1, 13, 15-17]:

(1) The coalbed is a homogeneous isotropic body

(2) Water and CBM filled the cracks in the coal

(3) Extraction desorption and adsorption are all completed in an instant

(4) The gas in coalbed is the ideal gas and does not consider the influence of temperature change on gas dynamic viscosity

2.1. Fluid Seepage Control Equation. The coalbed is full of methane and water. Under the pressure gradient, the methane and water continue to flow to the surface well. The process can be described by the fluid continuity equation [18]:

$$
\frac{\partial m}{\partial t}+\nabla \cdot\left(-\frac{\rho k}{\mu} \Delta p\right)=Q
$$

where $Q$ is the quality source, $\mathrm{kg} /\left(\mathrm{m}^{3} \cdot \mathrm{s}\right) ; m$ is the mass of fluid per unit volume of coal, $\mathrm{kg} / \mathrm{m}^{3} ; \rho$ is the fluid density in the coalbed, $\mathrm{kg} / \mathrm{m}^{3} ; \vec{q}_{g}=-(k / \mu) \Delta p$ is the fluid seepage velocity in the coalbed, $\mathrm{m} / \mathrm{s} ; k$ is the coalbed permeability, $\mathrm{m}^{2} ; \mu$ is the dynamic viscosity of gas, Pa.s; $p$ is coalbed pressure, $\mathrm{Pa}$.

The methane mass per unit volume of coal can be expressed as [19]

$$
m_{g}=\rho_{g} \varphi s_{g}+(1-\varphi) \rho_{g a} \rho_{s} V_{c g}
$$



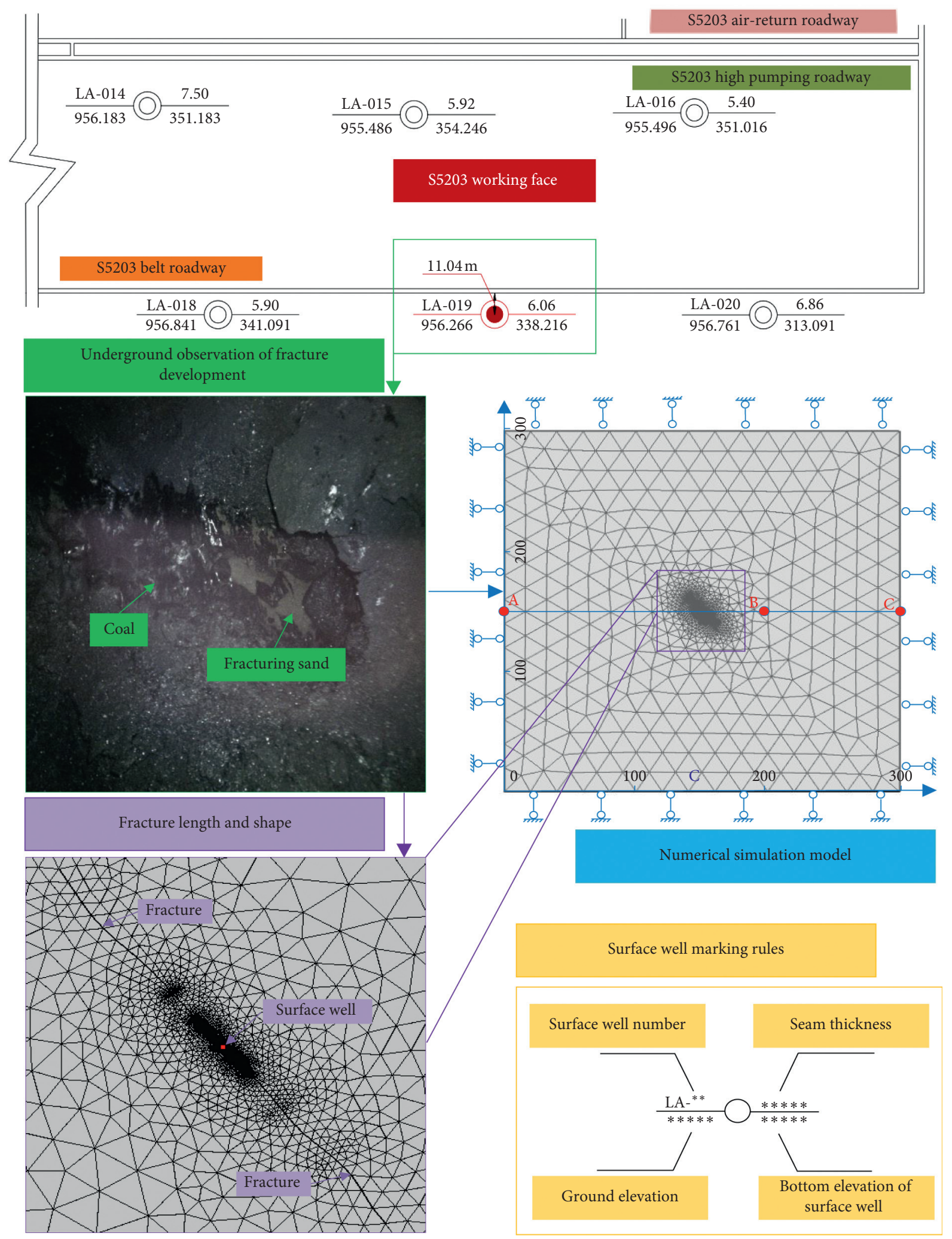

FIgURE 2: Establishment of numerical simulation model.

where $\varphi$ is the porosity; $\rho_{g a}$ is the gas density under standard conditions, $\mathrm{kg} / \mathrm{m}^{3} ; \rho_{s}$ is the density of coal skeleton, $\mathrm{kg} / \mathrm{m}^{3}$; $\rho_{g}=M_{g} P / R T$ is the methane density in the coal seam, $\mathrm{kg} / \mathrm{m}^{3} ; T$ is the coal seam temperature, $\mathrm{K}, \mathrm{m}^{3} / \mathrm{kg} ; M_{g}$ is the gas molar mass, $\mathrm{kg} / \mathrm{mol}$; $R$ the gas molar constant, $\mathrm{J} /(\mathrm{mol} \cdot \mathrm{K})$; $V_{c g}$ is the gas adsorbed per unit mass of coal volume [15]. 
TABLE 1: Numerical simulation parameters.

\begin{tabular}{|c|c|c|c|c|c|}
\hline Variable & Parameter & Value & Unit & Acquisition approach & Remark \\
\hline$E$ & Young's modulus of coal & 2710 & $\mathrm{MPa}$ & Experiments & \\
\hline$v$ & Poisson’s ratio & 0.3 & & Experiments & \\
\hline$E_{s}$ & Young's modulus of coal skeleton & 9520 & $\mathrm{MPa}$ & Experiments & \\
\hline$\alpha_{s}$ & Adsorption strain factor & 0.06 & $\mathrm{~kg} / \mathrm{m}^{3}$ & Experiments & \\
\hline$\rho_{s}$ & Density of coal skeleton & 1380 & $\mathrm{~kg} / \mathrm{m}^{3}$ & Experiments & \\
\hline$\varphi_{0}$ & Initial coalbed porosity & 0.037 & & Experiments & \\
\hline$P_{0}$ & Initial pressure of coalbed & 3.53 & $\mathrm{MPa}$ & Field data & \\
\hline$k_{0}$ & Initial coalbed permeability & $5.14 \times 10^{-16}$ & $\mathrm{~m}^{2}$ & Field data & \\
\hline$\mu_{g}$ & Dynamic viscosity coefficient of methane & $1.84 \times 10^{-5}$ & $\mathrm{~Pa} \cdot \mathrm{s}$ & References & {$[18]$} \\
\hline$\mu_{w}$ & Dynamic viscosity coefficient of water & 1.01 & $\mathrm{mPa} \cdot \mathrm{s}$ & References & {$[18]$} \\
\hline$\alpha_{T}$ & Thermal expansion coefficient & $2.4 \times 10^{-5}$ & $1 / \mathrm{K}$ & References & {$[28]$} \\
\hline$V_{L}$ & Langmuir volume constant & 0.02 & $\mathrm{~m}^{3} / \mathrm{kg}$ & Experiments & \\
\hline$P_{L}$ & Langmuir pressure constant & 0.96 & $\mathrm{MPa}$ & Experiments & \\
\hline$d_{1}$ & Langmuir pressure correction factor & 0.07 & $\mathrm{MPa}^{-1}$ & References & {$[28]$} \\
\hline$d_{2}$ & Langmuir temperature correction factor & 0.02 & $\mathrm{~K}^{-1}$ & References & {$[28]$} \\
\hline$T_{t}$ & Laboratory reference temperature & 300 & $\mathrm{~K}$ & References & {$[28]$} \\
\hline$C_{s}$ & Specific heat capacity of the coal skeleton & 1300 & $\mathrm{~J} /(\mathrm{kg} \cdot \mathrm{K})$ & References & {$[28]$} \\
\hline$C_{g}$ & Specific heat capacity of gas & 2550 & $\mathrm{~J} /(\mathrm{kg} \cdot \mathrm{K})$ & References & {$[28]$} \\
\hline$C_{w}^{y}$ & Specific heat capacity of water & 4200 & $\mathrm{~J} /(\mathrm{kg} \cdot \mathrm{K})$ & References & \\
\hline$\lambda_{s}$ & Heat conductivity of coal skeleton & 0.193 & $\mathrm{~W} /(\mathrm{m} \cdot \mathrm{K})$ & References & {$[28]$} \\
\hline$\lambda_{g}$ & Heat conductivity of gas & 0.031 & $\mathrm{~W} /(\mathrm{m} \cdot \mathrm{K})$ & References & {$[28]$} \\
\hline$\lambda_{w}^{y}$ & Heat conductivity of water & 0.598 & $\mathrm{~W} /(\mathrm{m} \cdot \mathrm{K})$ & References & {$[18]$} \\
\hline$q_{s t}^{\infty}$ & Isosteric heat of adsorption & 33.4 & $\mathrm{~J} / \mathrm{mol}$ & References & {$[28]$} \\
\hline$s_{w r}$ & Irreducible water saturation & 0.05 & & References & {$[18]$} \\
\hline$s_{g r}$ & Irreducible gas saturation & 0.05 & & References & {$[18]$} \\
\hline
\end{tabular}

$$
V_{c g}=\frac{V_{L} p_{m}}{P_{L}+p_{m}} \exp \left[-\frac{d_{2}}{1+d_{1} p_{m}}\left(T-T_{t}\right)\right],
$$

where $d_{1}$ is the pressure coefficient, $\mathrm{Pa}^{-1} ; d_{2}$ is the temperature coefficient, $\mathrm{K}^{-1} ; V_{L}$ is the Langmuir volume constant, $\mathrm{m}^{3} / \mathrm{kg} ; P_{L}$ is the Langmuir pressure constant, $\mathrm{Pa}$; $T_{t}$ is the laboratory reference temperature, $\mathrm{K}$.

The mass of water per unit volume of coal can be expressed as

$$
m_{w}=\rho_{w} \varphi s_{w}
$$

where $s_{w}$ is the water saturation in the coalbed; $\rho_{w}$ is the density of water, $\mathrm{kg} / \mathrm{m}^{3}$.

The fluid seepage velocity in the coalbed can be expressed as

$$
\left\{\begin{array}{l}
k_{g}=k k_{r g} \\
k_{w}=k k_{r w}
\end{array}\right.
$$

According to the relative permeability model of porous media [20-23],

$$
\left\{\begin{array}{l}
k_{r w}=\left(\frac{s_{w}-s_{w r}}{1-s_{w r}}\right)^{4}, \\
k_{r g}=\left[1-\left(\frac{s_{w}-s_{w r}}{1-s_{w r}-s_{g r}}\right)\right]^{2}\left[1-\left(\frac{s_{w}-s_{w r}}{1-s_{w r}}\right)^{2}\right],
\end{array}\right.
$$

where $s_{w r}$ is the irreducible water saturation; $s_{g r}$ is the irreducible gas saturation.
Simultaneous formulas (1)-(5) are the seepage control equation of methane and water in the coalbed which can be expressed as

$$
\begin{array}{r}
\frac{\partial\left(\rho_{w} \varphi s_{w}\right)}{\partial t}+\nabla \cdot\left(-\frac{\rho_{w} k k_{r w}}{\mu_{w}} \Delta p_{w}\right)=Q_{w} \\
\frac{\partial\left(\rho_{g} \varphi s_{g}+(1-\varphi) \rho_{g a} \rho_{s} V_{c g}\right)}{\partial t}+\nabla \cdot\left(-\frac{\rho_{g} k k_{r g}}{\mu_{g}} \Delta p_{g}\right)=Q_{g}
\end{array}
$$

where $\mu_{w}$ and $\mu_{g}$ are dynamic viscosity coefficients of water and methane, respectively.

2.2. Control Equation of Coalbed Stress Field. The Navier equation of coal space balance is [24-26]

$$
\sigma_{i j, j}+F_{i}=0,
$$

where $\sigma_{i j}$ is the total stress in the coal, $\mathrm{N} ; F_{i}$ is the volume force component, $\mathrm{N}$.

The Cauchy equation satisfied by the strain component and displacement component of the coal body is

$$
\varepsilon_{i j}=\frac{1}{2}\left(u_{i, j}+u_{j, i}\right)
$$

where $\varepsilon_{i j}$ is the component of strain tensor, $\mathrm{m}$; $u$ is the displacement component, $\mathrm{m}$.

Under the action of surface well, the amount of methane adsorption and temperature and stress on coal are constantly changing. The constitutive equation of coal 
TABLE 2: Simulation strategy.

\begin{tabular}{|c|c|}
\hline Program & Model \\
\hline Case 1: influence of initial permeability on methane extraction effect of hydraulic fracturing well & $\begin{array}{l}\text { Model 1: } k_{0}=5 \times 10^{-17} \mathrm{~m}^{2} \\
\text { Model 2: } k_{0}=9 \times 10^{-17} \mathrm{~m}^{2} \\
\text { Model 3: } k_{0}=13 \times 10^{-17} \mathrm{~m}^{2} \\
\text { Model 4: } k_{0}=17 \times 10^{-17} \mathrm{~m}^{2}\end{array}$ \\
\hline Case 2: influence of initial coalbed pressure on methane extraction effect of hydraulic fracturing well & $\begin{array}{l}\text { Model 1: } P_{0}=2.53 \mathrm{MPa} \\
\text { Model 2: } P_{0}=3.53 \mathrm{MPa} \\
\text { Model 3: } P_{0}=4.53 \mathrm{MPa} \\
\text { Model 4: } P_{0}=5.53 \mathrm{MPa}\end{array}$ \\
\hline Case 3: influence of fracture length on methane extraction effect of hydraulic fracturing well & $\begin{array}{l}\text { Model 1: } L=10 \mathrm{~m} \\
\text { Model 2: } L=15 \mathrm{~m} \\
\text { Model 3: } L=20 \mathrm{~m} \\
\text { Model 4: } L=25 \mathrm{~m}\end{array}$ \\
\hline
\end{tabular}

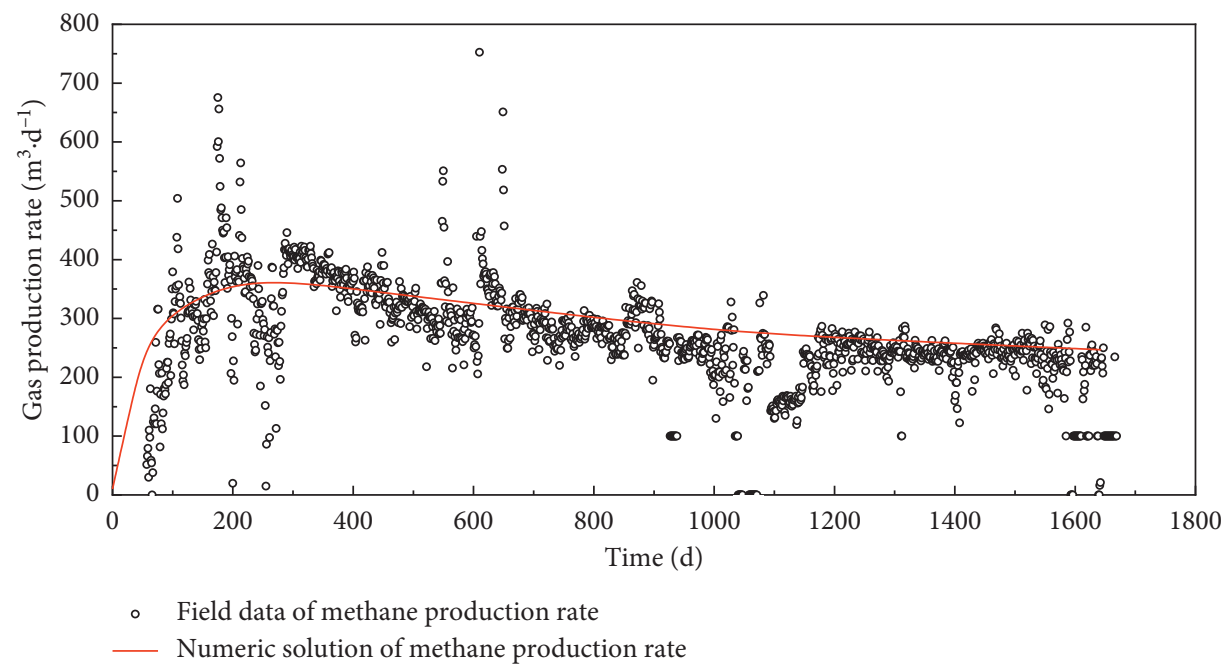

Figure 3: Comparison of numeric solution of methane production rate and field data of methane production rate.

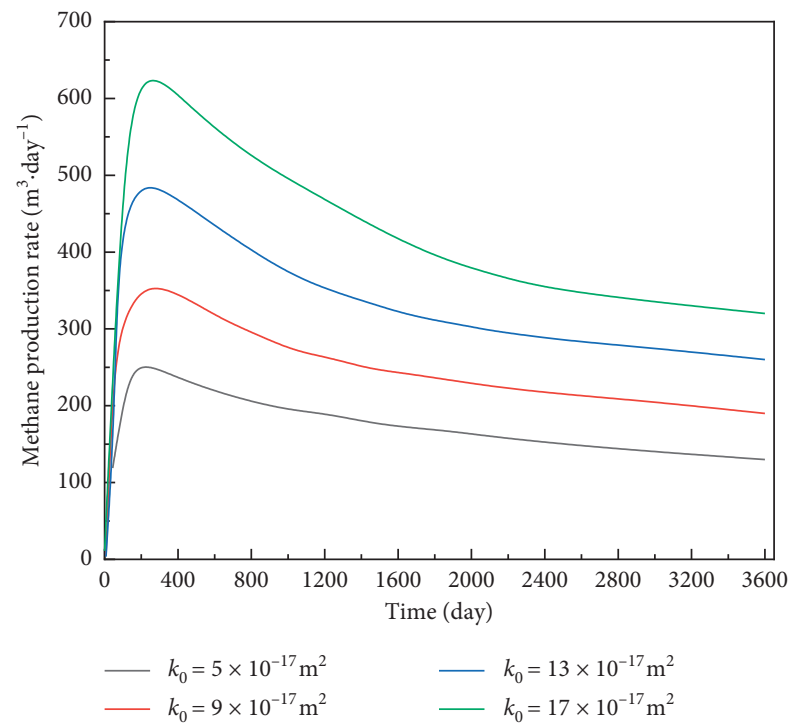

FIGURE 4: Variation of methane production rate with different initial coalbed permeability. 

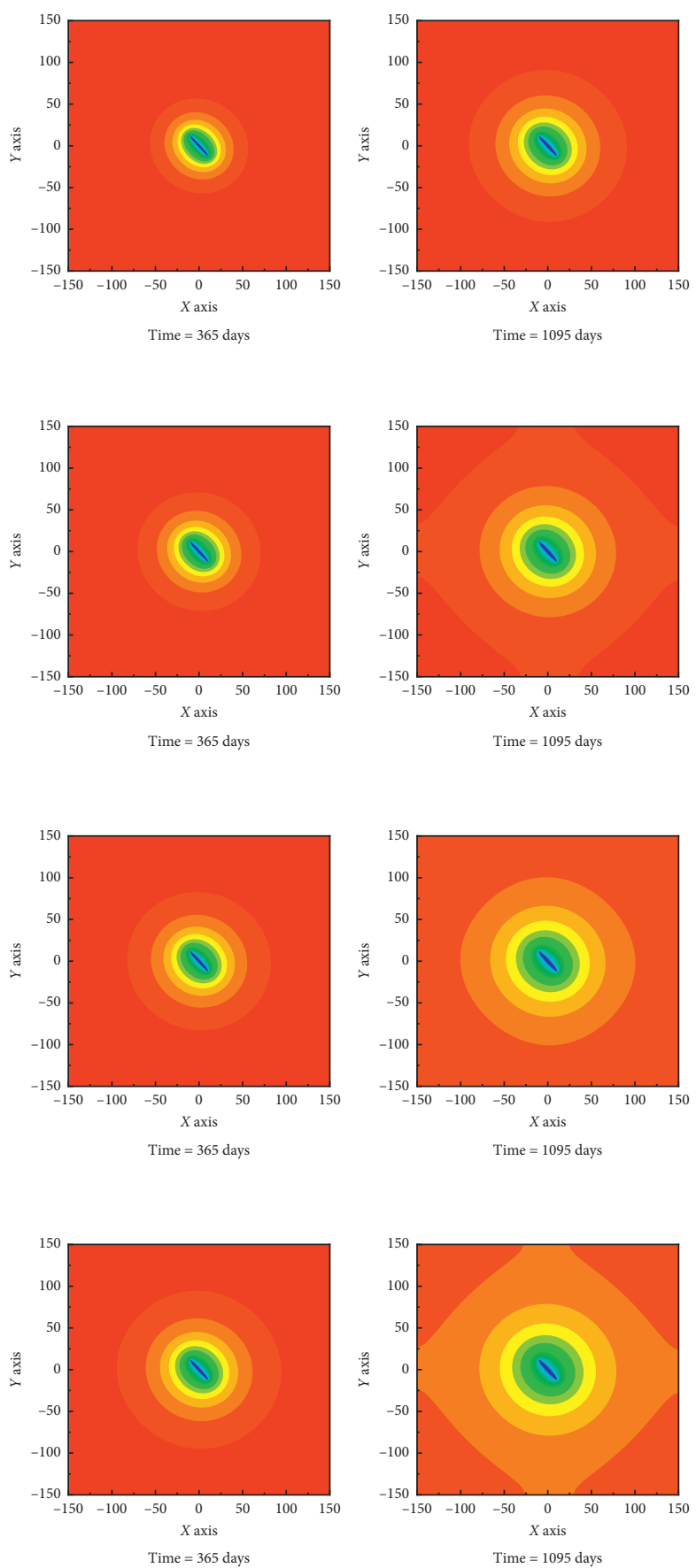

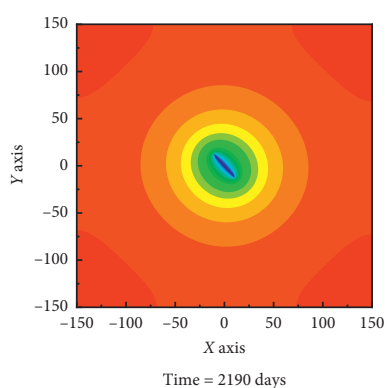

(a)
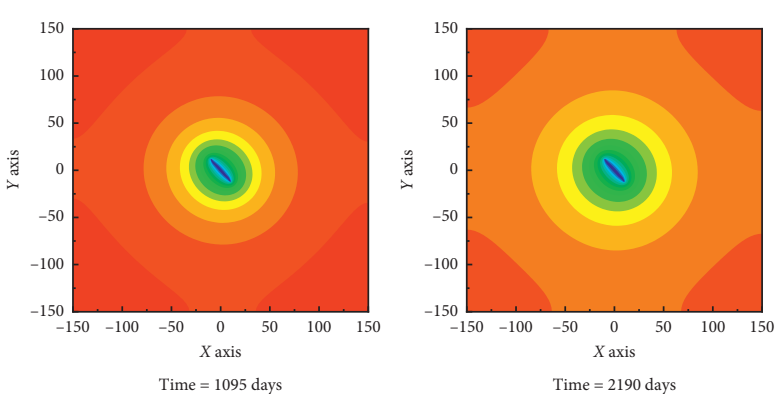

(b)
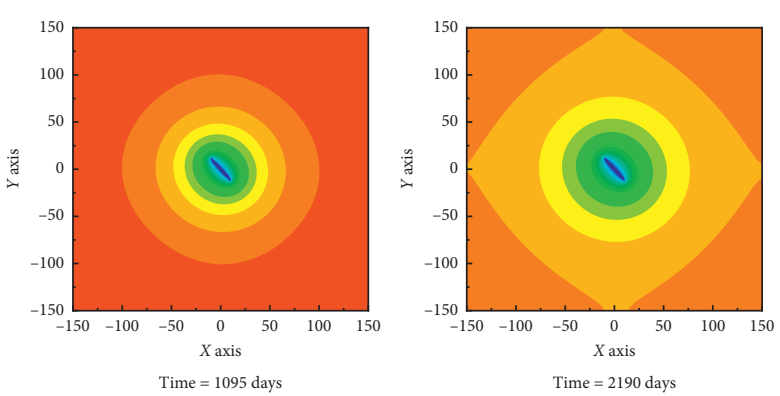

(c)

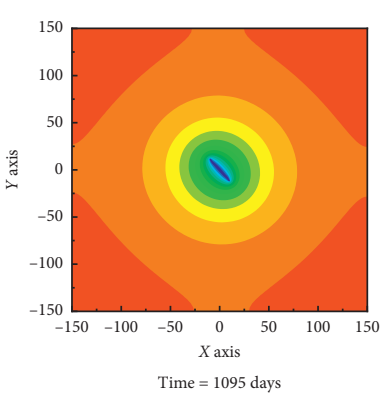

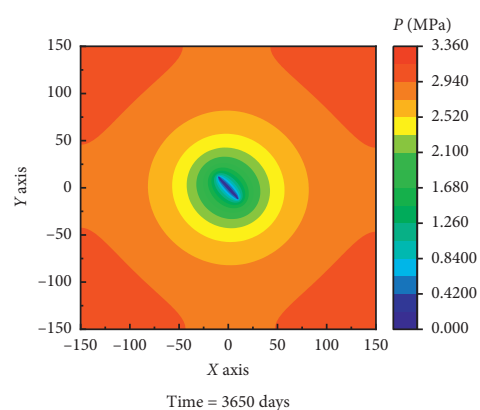

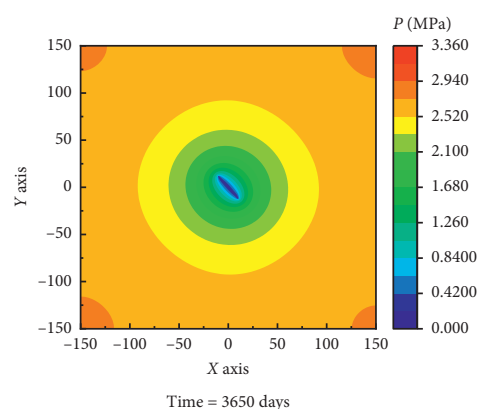

Time $=3650$ days
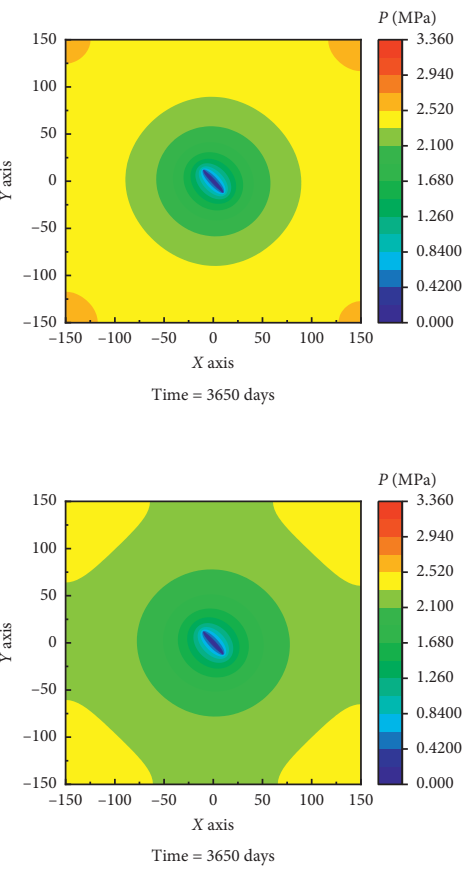

(d)

FiguRE 5: Variation of coalbed methane pressure with different initial coalbed permeability. (a) $k_{0}=5 \times 10^{-17} \mathrm{~m}^{2}$. (b) $k_{0}=9 \times 10^{-17} \mathrm{~m}^{2}$. (c) $k_{0}=13 \times 10^{-17} \mathrm{~m}^{2}$. (d) $k_{0}=17 \times 10^{-17} \mathrm{~m}^{2}$.

hydraulic-mechanical-thermal coupling based on the theory of porous media can be expressed as $[27,28]$

$$
\begin{aligned}
\varepsilon_{i j}= & \frac{1}{2 G} \sigma_{i j}-\left(\frac{1}{6 G}-\frac{1}{9 K}\right) \sigma_{k k} \delta_{i j}+\frac{\alpha}{3 K} p_{g} \delta_{i j} \\
& +\frac{\alpha_{T}}{3}\left(T-T_{0}\right) \delta_{i j}+\frac{\varepsilon_{a}}{3} \delta_{i j},
\end{aligned}
$$

where $G$ is the Lame coefficient, $G=E /(2+2 v), \mathrm{Pa} ; E$ is Young's modulus of the coal, $\mathrm{Pa} ; K$ is the bulk modulus of the coal, $\mathrm{Pa} ; \alpha=1-K / K_{s}$ is Biot coefficient of coal; $K_{s}$ is the bulk modulus of coal matrix, $\mathrm{Pa} ; \alpha_{T}$ is the volume thermal expansion coefficient, $1 / \mathrm{K} ; \varepsilon_{a}=\alpha_{a} \Delta V_{c g}$ is the adsorption strain; $\alpha_{a}$ is the adsorption strain coefficient, $\mathrm{kg} / \mathrm{m}^{3} ; \delta_{i j}$ is the Kronecker symbol; $v$ is the coal body's Poisson's ratio. 


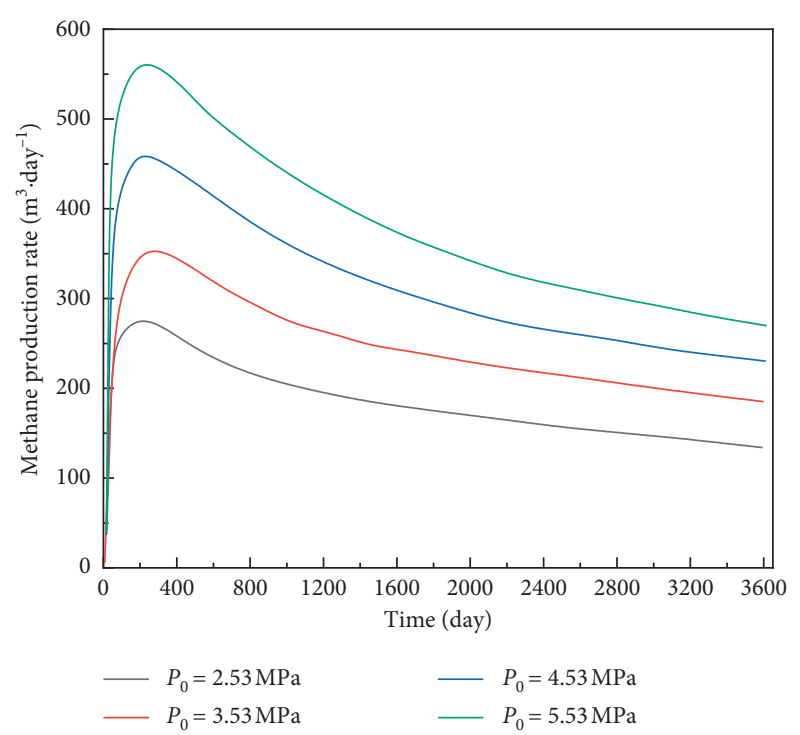

FIgURE 6: Variation of methane production rate with different initial coalbed pressure.

Combining (8)-(10) can obtain the control equation of coalbed stress field:

$$
G u_{i, j j}+\frac{G}{1-2 \nu} u_{j, j i}-\alpha p_{g, i}-K \varepsilon_{s, i}-K \alpha_{T} T_{i}+F_{i}=0 .
$$

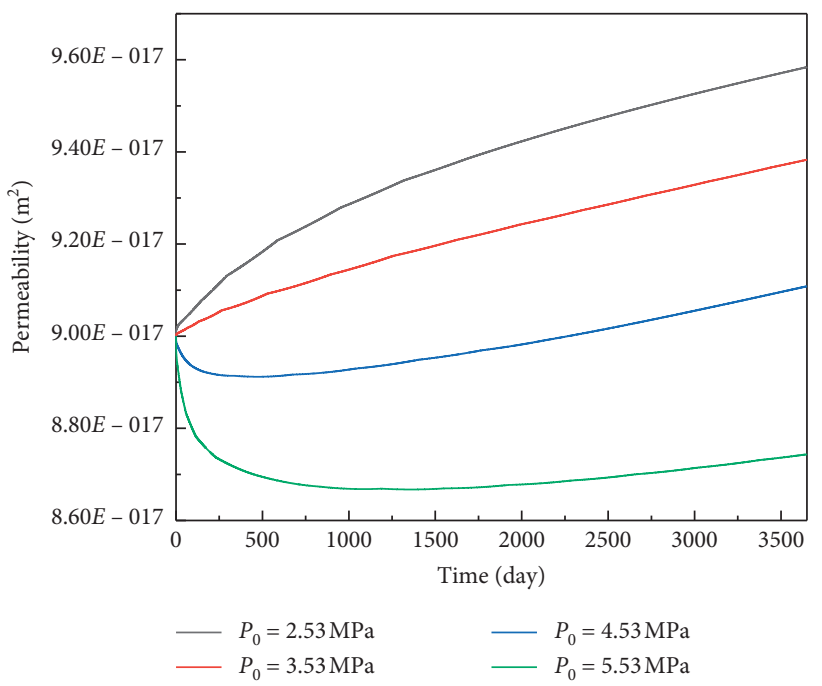

FIGURE 7: Variation of coalbed permeability with different initial coalbed pressure at the reference point $\mathrm{B}$.

2.3. Control Equation of Coalbed Temperature Field. Under the action of surface well, there is temperature exchange between methane, water, and coal skeleton in the coalbed. According to the first law of thermodynamics, the coalbed temperature field control equation can be expressed as

$$
\begin{gathered}
\frac{\partial\left(\left(\rho C_{p}\right)_{c} T\right)}{\partial t}+\eta \nabla T-\nabla \\
\left(\rho C_{p}\right)_{c}=(1-\varphi) \rho_{s} C_{s}+\varphi s_{g} \rho_{g} C_{g}+\varphi s_{w} \rho_{w} C_{w} \\
\eta=-\frac{k k_{r g}}{\mu_{g}} \nabla p_{g} \rho_{g} C_{g}-\frac{k k_{r w}}{\mu_{w}} \nabla p_{w} \rho_{w} C_{w} \\
\lambda=(1-\varphi) \lambda_{s}+s_{g} \varphi \lambda_{g}+s_{w} \varphi \lambda_{w}
\end{gathered}
$$

where $C_{g}$ is the specific heat capacity of methane, $\mathrm{J} /\left(\mathrm{m}^{3} \cdot \mathrm{K}\right)$; $\lambda_{g}$ is the thermal conductivity of methane, $\mathrm{W} /(\mathrm{m} \cdot \mathrm{K}) ; C_{s}$ is the specific heat capacity of the coal skeleton, $\mathrm{J} /\left(\mathrm{m}^{3} \cdot \mathrm{K}\right) ; \lambda_{s}$ is the thermal conductivity of the coal skeleton, $\mathrm{W} /(\mathrm{m} \cdot \mathrm{K}) ; q_{s t}$ is the equivalent heat of adsorption, J/mol; $\left(\rho C_{p}\right)_{c}$ is the effective specific heat capacity of coal and coal bed gas, $\mathrm{J} /\left(\mathrm{m}^{3} \cdot \mathrm{K}\right) ; \eta$ is the convection coefficient, $\mathrm{J} /\left(\mathrm{m}^{2} \cdot \mathrm{s}\right) ; \lambda_{c}$ is the thermal conductivity of coal skeleton and coal bed gas, $\mathrm{W} /(\mathrm{m} \cdot \mathrm{K})$.

$$
k=k_{0}\left(\frac{1}{\varphi_{0}}-\frac{\left(1-\varphi_{0}\right)}{\varphi_{0}(1+e)}\left(1-\frac{\alpha}{K} \Delta p+\alpha_{T} \Delta T+\alpha_{a}\left(V_{c g}-V_{c g 0}\right)\right)\right)^{3}
$$

2.4. Cross Coupling. During the process of CBM extraction in surface wells, the continuous change of coalbed porosity under the influence of stress, temperature, and methane desorption can be expressed as [29]

$$
\varphi=1-\frac{\left(1-\varphi_{0}\right)}{1+e}\left(1-\frac{\alpha}{K} \Delta p+\alpha_{T} \Delta T+\alpha_{a}\left(V_{c g}-V_{c g 0}\right)\right)
$$

where $\varphi_{0}$ is the initial coalbed porosity.

Considering coal body damage, the coalbed permeability during methane extraction can be expressed as [30]

where $k_{0}$ is the initial coalbed permeability, $\mathrm{m}^{2}$. 

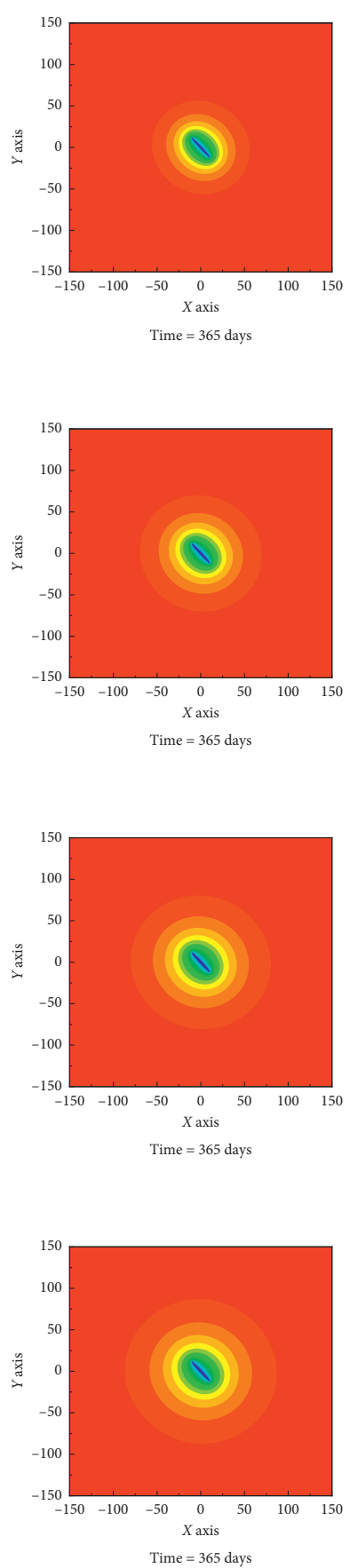
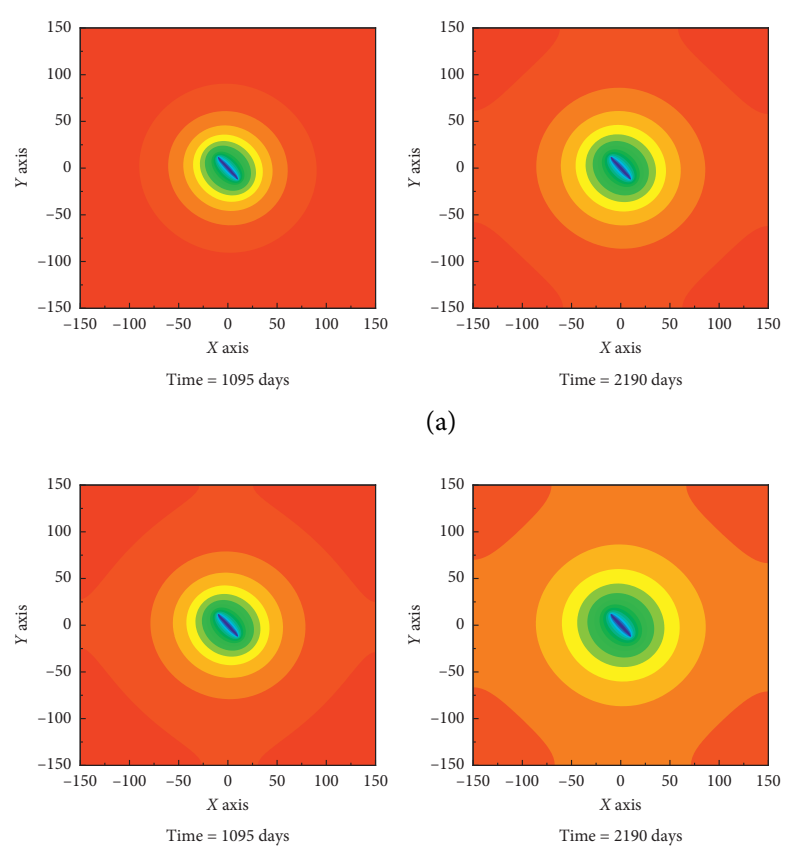

(a)

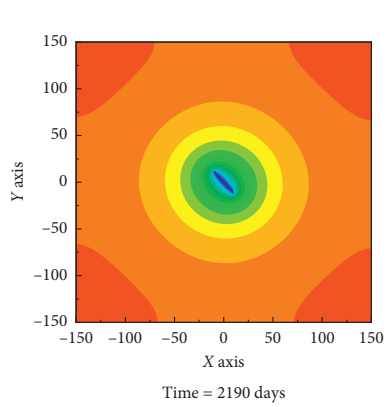

(b)
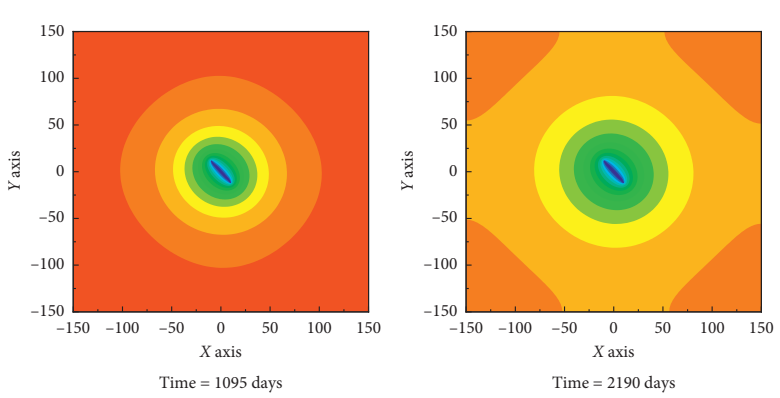

(c)

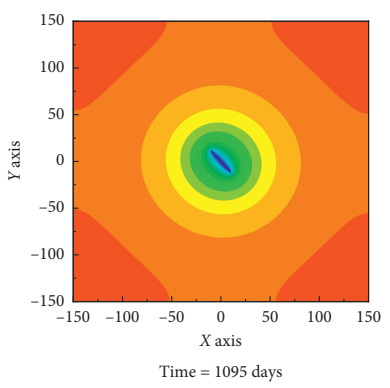

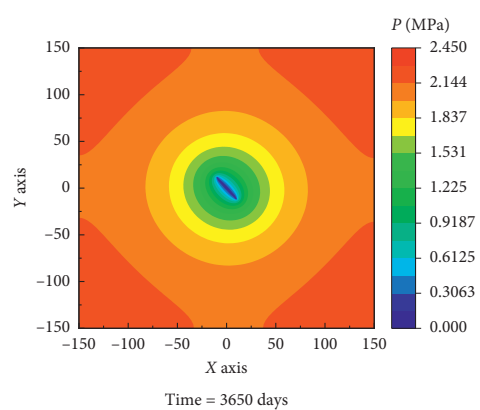
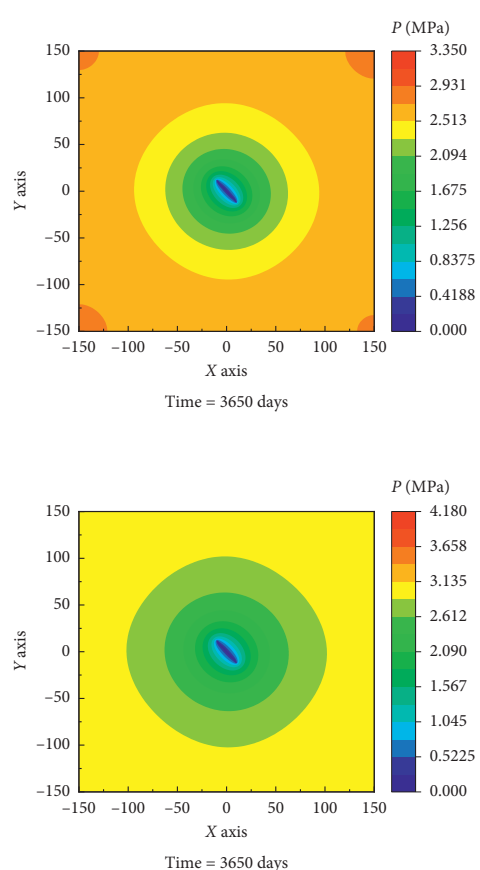

Time $=3650$ days

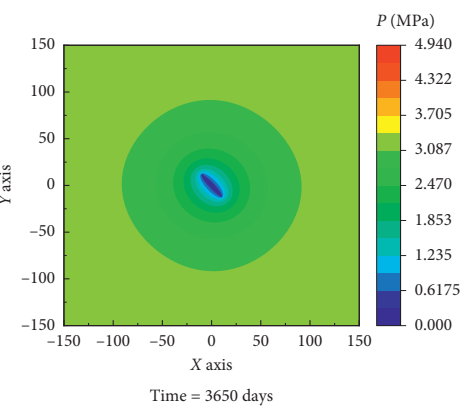

(d)

Figure 8: Variation of coalbed methane pressure with different initial coalbed pressure. (a) $P_{0}=2.53 \mathrm{MPa}$. (b) $P_{0}=3.53 \mathrm{MPa}$. (c) $P_{0}=4.53 \mathrm{MPa}$. (d) $P_{0}=5.53 \mathrm{MPa}$.

\section{Model Validation}

Yuwu Coal Mine is located in the east wing of Qinshui Basin in China, with a minefield area of $160.24 \mathrm{~km}^{2}$. The main coalbed is $3 \#$, with an average coalbed thickness of $6 \mathrm{~m}$ and a methane reserve of $16,568.519 \mathrm{Mm}^{3}$. Due to the large methane content in the minefield, the low coalbed permeability, and the difficulty of methane extraction, Yuwu Coal Mine has constructed 170 surface wells since 2008, of which 124 are hydraulic fracturing wells. The overall structure of the coal mine is gently dipping and monoclinic. On this basis, the development direction is relatively single and wide and gentle folds (the dip angle of the two wings is generally less than $10^{\circ}$ ); along the dip and strike, there are a small number of faults with a fault distance greater than $20 \mathrm{~m}$ and a certain number of faults less than $20 \mathrm{~m}$ fault and collapse column. 
In order to analyze the impact of coalbed hydraulic fracturing on methane extraction, the LA-019 surface fracturing well of Yuwu Coal Mine is taken as the simulation object. The model size is $300 \mathrm{~m} \times 300 \mathrm{~m}$. The fracture development length and shape are obtained from underground observations. The two main fractures are distributed on both sides of the fracturing well, with a one-way length of about $15 \mathrm{~m}$ and an azimuth angle of $50^{\circ}$ (Figure 2). The external boundary of this model is restrained from boundary-normal displacements and insulated for gas and thermal transport.

In order to facilitate the observation of the simulation effect, reference point $\mathrm{B}$ and reference line $\mathrm{AC}$ are set, and the coordinates of points A, B, and C are $(0,150),(200,150)$, and $(300,150)$, respectively. Numerical simulation parameters come from the field, tests, or references (Table 1). In order to study the influence of initial coalbed pressure, initial permeability, and fracture length on the methane extraction effect of hydraulic fracturing well, the three sets of data were simulated by the controlled variable method (Table 2).

In order to verify the accuracy of the model, the methane production rate data of LA-019 surface fracturing well in Yuwu Coal Mine was compared with the numerical simulation data (the calculation of gas production is in standard state). As illustrated in Figure 3, although the field data fluctuates, there is a clear trend of change. The simulation results are highly matched with the field data, indicating that the built model can be used for methane extraction research in hydraulic fracturing wells.

\section{Numerical Simulation of Methane Extraction in Hydraulic Fracturing Well}

4.1. Influence of Initial Permeability on Methane Extraction Effect of Hydraulic Fracturing Well. Figure 4 shows the variation of methane production rate with different initial coalbed permeability. As illustrated in Figure 4, the methane production rate of hydraulic fracturing wells gradually increases first and then gradually decreases. When the initial coalbed permeability $k_{0}=5 \quad \mathrm{t}^{-17} \mathrm{~m}^{2}, 9 \quad 910^{-17} \mathrm{~m}^{2}, 13$ $110^{-17} \mathrm{~m}^{2}, 17110^{-17} \mathrm{~m}^{2}$, the peak methane production rate is $254.29 \mathrm{~m}^{3} /$ day, $\quad 361.99 \mathrm{~m}^{3} /$ day, $\quad 490.21 \mathrm{~m}^{3} /$ day, and $647.80 \mathrm{~m}^{3} /$ day, respectively. Making the initial coalbed permeability $k_{0}=5 \mathrm{da}^{-17} 0^{-17} \mathrm{~m}^{2}$ as a reference, the peak methane production rate of $k_{0}=9 \mathrm{as} 10^{-17} \mathrm{~m}^{2}, 133 \mathrm{~s}^{-10^{-17}} \mathrm{~m}^{2}$, $177 \mathrm{~s}^{-17} \mathrm{~m}^{2}$ is increased by $42.35 \%, 92.78 \%$, and $154.75 \%$, respectively.

Figure 5 shows the variation of coalbed methane pressure with different initial coalbed permeability. As illustrated in Figure 5, the greater the initial coalbed permeability, the better the methane extraction effect of hydraulic fracturing well. When the initial coalbed permeability $k_{0}=5 \mathrm{t}^{-17} \mathrm{~m}^{2}$, $9910^{-17} \mathrm{~m}^{2}, 13110^{-17} \mathrm{~m}^{2}, 17110^{-17} \mathrm{~m}^{2}$, after $3650 \mathrm{~d}$ of extraction, the average methane pressure of the coalbed is $2.79 \mathrm{MPa}, 2.52 \mathrm{MPa}, 2.32 \mathrm{MPa}$, and $2.17 \mathrm{MPa}$, respectively. Making the initial coalbed permeability $k_{0}=5 \mathrm{~Pa}^{-17} \mathrm{~m}^{2}$ as a reference, the average methane pressure of $k_{0}=9$ as $10^{-17} \mathrm{~m}^{2}$, $133 \mathrm{~s}^{-17} \mathrm{~m}^{2}, 177 \mathrm{~s} 10^{-17} \mathrm{~m}^{2}$ is decreased by $9.38 \%, 16.84 \%$, and $22.22 \%$, respectively.

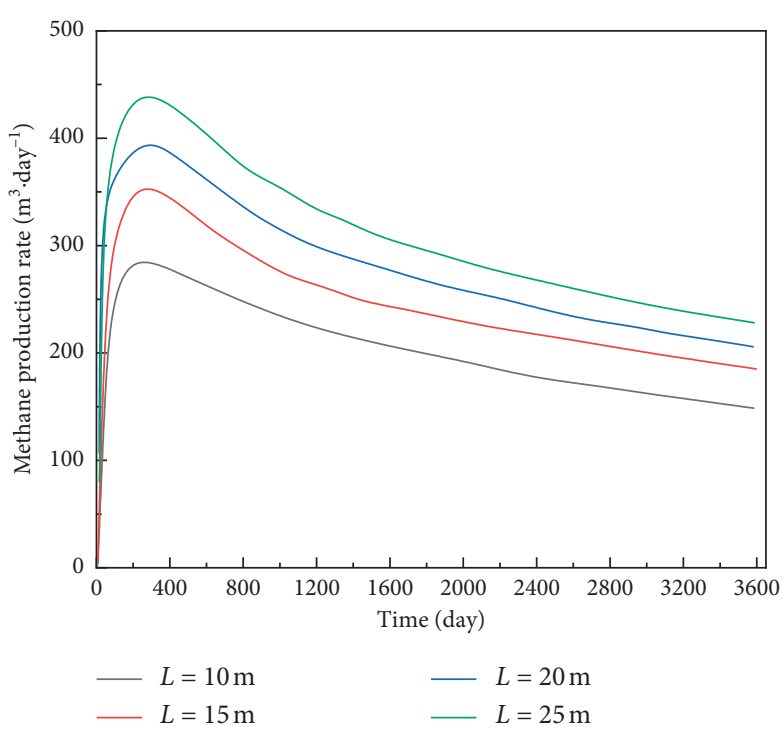

FIGURE 9: Variation of methane production rate with different fracture length.

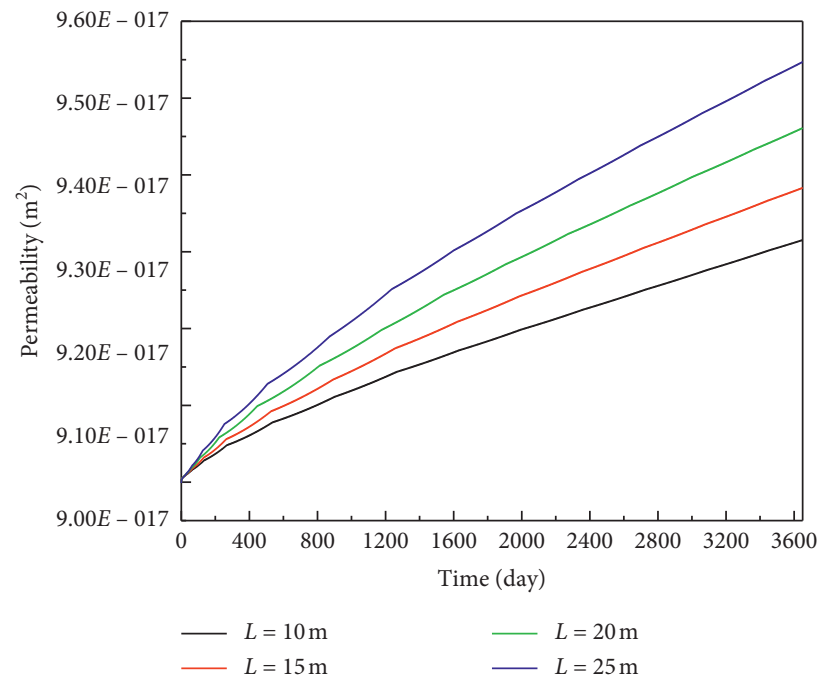

Figure 10: Variation of coalbed permeability with different fracture length at the reference point $\mathrm{B}$.

4.2. Influence of Initial Coalbed Pressure on Methane Extraction Effect of Hydraulic Fracturing Well. Figure 6 shows the variation of methane production rate with different initial coalbed pressure. As illustrated in Figure 6, because the coalbed methane seepage velocity is greatly affected by the methane pressure gradient, increasing the initial reservoir pressure increases the pressure gradient between the coalbed and the extraction well, and the methane production of hydraulic fracturing well increases. When the initial coalbed pressure is $P_{0}=2.53 \mathrm{MPa}, 3.53 \mathrm{MPa}, 4.53 \mathrm{MPa}$, and $5.53 \mathrm{MPa}$, the peak methane production rate is $284.21 \mathrm{~m}^{3} /$ day, $312.87 \mathrm{~m}^{3} /$ day, $\quad 413.16 \mathrm{~m}^{3} /$ day, and $509.21 \mathrm{~m}^{3} /$ day, respectively.

Figure 7 shows the variation of coalbed permeability with different initial coalbed pressure at the reference point B. As illustrated in Figure 7, during the process of methane 

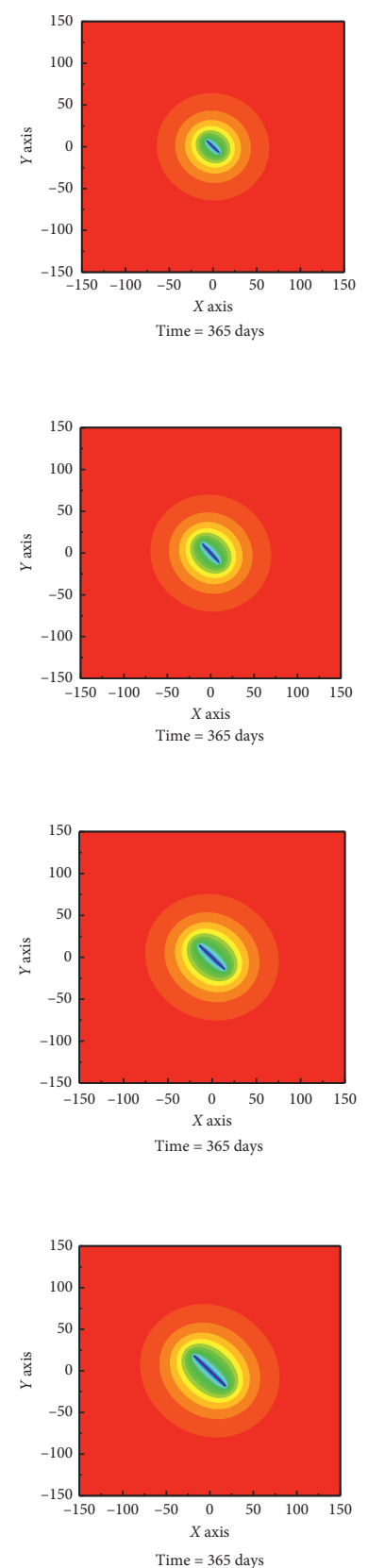
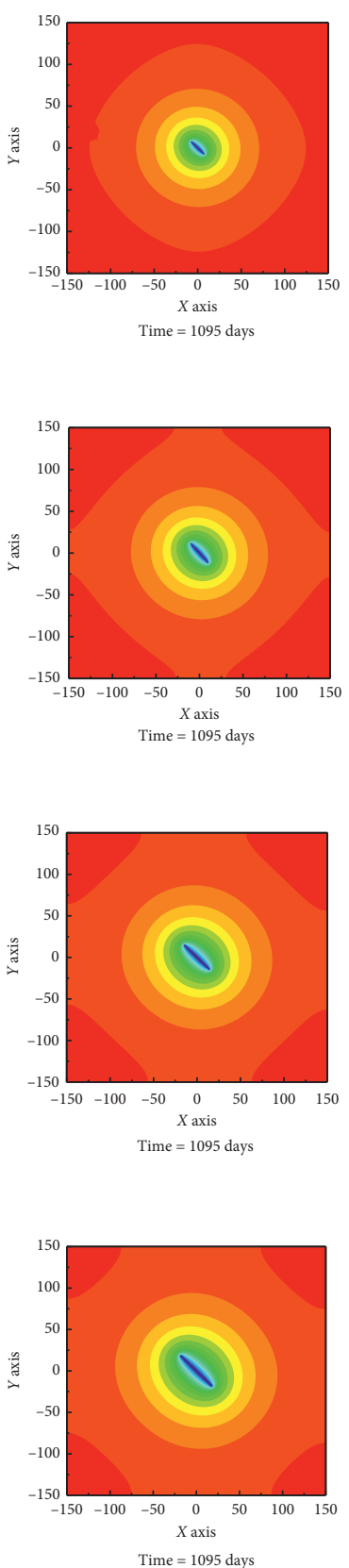

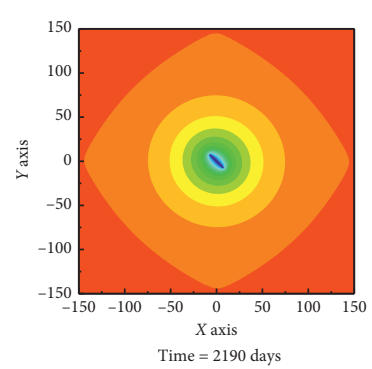

(a)

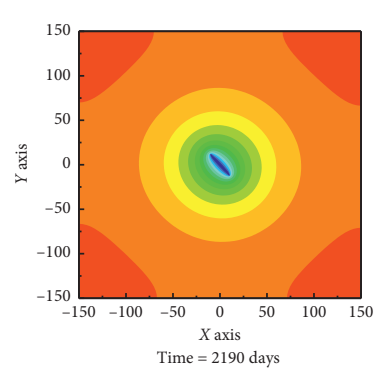

(b)

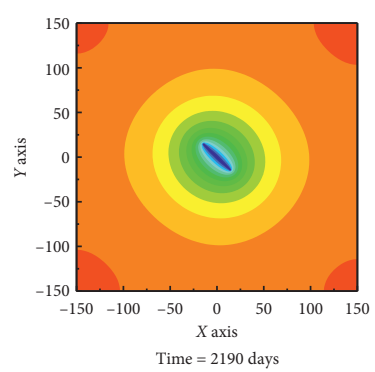

(c)
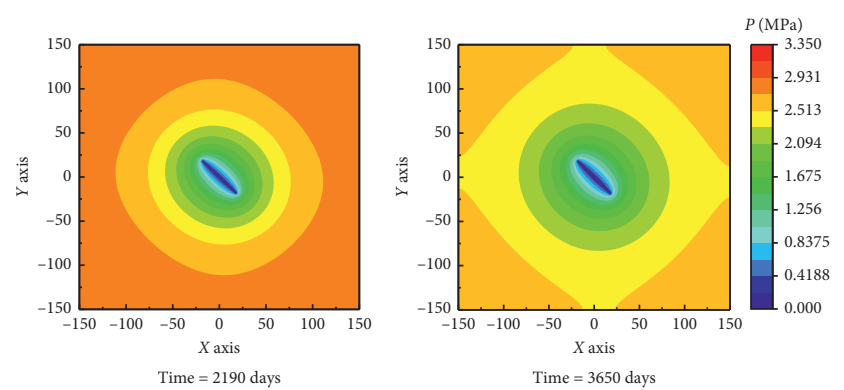
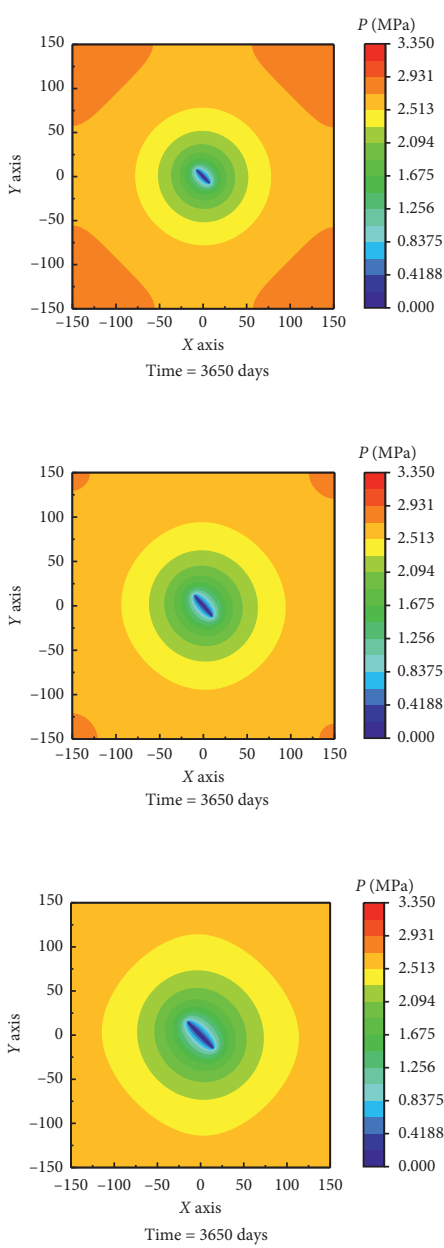

Time $=3650$ day

(d)

FIGURE 11: Variation of coalbed methane pressure with different fracture length. (a) $L=10 \mathrm{~m}$. (b) $L=15 \mathrm{~m}$. (c) $L=20 \mathrm{~m}$. (d) $L=25 \mathrm{~m}$.

extraction, coalbeds with different initial pressure have different trend in permeability. This is because the changes in coalbed permeability are the result of competition between two factors: the coal matrix shrinkage caused by temperature reduction and methane desorption and the coal matrix expansion caused by methane pressure decrease. When the methane pressure is high, the matrix expansion caused by methane pressure decrease dominates and the permeability decreases.

Figure 8 shows the variation of coalbed methane pressure with different initial coalbed pressure. As illustrated in Figure 8 , although the permeability of the high initial pressure coalbed is lower than the low initial pressure coalbed in the process of methane extraction, the higher the initial pressure under the influence of the pressure gradient, the greater the average methane pressure drop of the coal seam bed in the same time of extraction.

4.3. Influence of Fracture Length on Methane Extraction Effect of Hydraulic Fracturing Well. Figure 9 shows the variation of methane production rate with different fracture length. As illustrated in Figure 9, fractures increase the methane migration channel of the coalbed. The longer the fracture 
length is, the greater the methane production rate is. When the fracture length $L=10 \mathrm{~m}, 15 \mathrm{~m}, 20 \mathrm{~m}$, and $25 \mathrm{~m}$, the peak methane production rate is $294.03 \mathrm{~m}^{3} /$ day, $361.99 \mathrm{~m}^{3} /$ day, $402.42 \mathrm{~m}^{3} /$ day, and $451.45 \mathrm{~m}^{3} /$ day, respectively.

Figure 10 shows the variation of coalbed permeability with different fracture length at the reference point $\mathrm{B}$. As illustrated in Figure 10, affected by the efficiency of methane extraction, the permeability of the coalbed increases with the length of the fracture in the same extraction time. When the fracture length $L=10 \mathrm{~m}, 15 \mathrm{~m}, 20 \mathrm{~m}$, and $25 \mathrm{~m}$, after 3650 days of extraction, the permeability at the reference point $\mathrm{B}$ is $9.32 e^{-17} \mathrm{~m}^{2}, 9.38 e^{-17} \mathrm{~m}^{2}, 9.46 e^{-17} \mathrm{~m}^{2}$, and $9.55 e^{-17} \mathrm{~m}^{2}$, respectively.

Figure 11 shows the variation of coalbed methane pressure with different fracture length. As illustrated in Figure 11, the longer the fracturing fracture is, the higher the extraction efficiency is. When the fracture length $L=10 \mathrm{~m}$, $15 \mathrm{~m}, 20 \mathrm{~m}$, and $25 \mathrm{~m}$, the average methane pressure of the coalbed is $2.79 \mathrm{MPa}$, 2.52 MPa, 2.32 MPa, and $2.17 \mathrm{MPa}$ after 3650 days of extraction. Making the fracture length $L=10 \mathrm{~m}$ as a reference, the average coalbed methane pressure of $L=15 \mathrm{~m}, 20 \mathrm{~m}$, and $25 \mathrm{~m}$ is decreased by $9.38 \%, 16.84 \%$, and $22.22 \%$, respectively.

\section{Conclusions}

In this work, a hydraulic-mechanical-thermal coupled model for CBM extraction in hydraulic fracturing well is established, and it combines gas-liquid two-phase infiltration, where nonisothermal adsorption is also considered. The COMSOL Multiphysics software is used to carry out the numerical simulation study of the CBM extraction process in hydraulic fracturing well and analyze the influence of coalbed permeability, initial pressure, and fracture length on CBM extraction in hydraulic fracturing well. The following conclusions can be drawn:

(1) The hydraulic-mechanical-thermal coupled model for CBM extraction in hydraulic fracturing well established includes methane desorption, coal deformation, temperature exchange, and gas-water seepage. The numerical simulation effect of the model can be highly consistent with the field data, and it can be used for CBM extraction research in hydraulic fracturing well.

(2) The initial coalbed permeability, initial methane pressure, and fracture length all affect the migration speed of CBM to the hydraulic fracturing well in different ways. The greater the initial coalbed permeability and methane pressure is, the longer the fracture length is and the greater the $\mathrm{CMB}$ production rate of hydraulic fracturing well is.

(3) The change trend of coalbed permeability during the extraction process of surface fracturing well is directly related to the state of the reservoir. The factors of stress, temperature, and CBM desorption jointly determine the increase or decrease of coal seam permeability.

\section{Data Availability}

The data used to support the findings of this study are included within the article.

\section{Conflicts of Interest}

The authors declare no conflicts of interest.

\section{Authors' Contributions}

The numerical simulation model was established by Yongpeng fan, Longyong Shu, and Zhonggang Huo. The field data were tracked and investigated by Jinwei Hao and Yang Li. All authors participated in data analysis and manuscript writing.

\section{Acknowledgments}

The work was financially supported by the National Key Research and Development Project (2018YFB0605601) and Science and Technology Innovation and Entrepreneurship Fund Special Project of Tiandi Technology Co., Ltd. (2020TD-MS003).

\section{References}

[1] C. Guo, J. Xu, M. Wei, and R. Jiang, "Experimental study and numerical simulation of hydraulic fracturing tight sandstone reservoirs," Fuel, vol. 159, pp. 334-344, 2015.

[2] J. Yun, F. Xu, L. Liu, N. Zhong, and X. Wu, "New progress and future prospects of CBM exploration and development in China," International Journal of Mining Science and Technology, vol. 22, no. 3, pp. 363-369, 2012.

[3] X. Su, F. Li, L. Su, and Q. Wang, "The experimental study on integrated hydraulic fracturing of coal measures gas reservoirs," Fuel, vol. 270, Article ID 117527, 2020.

[4] Q. Wang, Y. Wang, M. He et al., "Experimental research and application of automatically formed roadway without advance tunneling," Tunnelling and Underground Space Technology, vol. 114, Article ID 103999, 2021.

[5] T. Wang, W. Zhou, J. Chen, X. Xiao, Y. Li, and X. Zhao, "Simulation of hydraulic fracturing using particle flow method and application in a coal mine," International Journal of Coal Geology, vol. 121, pp. 1-13, 2014.

[6] C. A. Wright and R. A. Conant, "Hydraulic fracture reorientation in primary and secondary recovery from lowpermeability reservoirs," in Proceedings of the SPE Annual Technical Conference and Exhibition Delta, pp. 357-369, Austin, TX, USA, October 1995.

[7] T. Yan, W. Li, and X. Bi, "An experimental study of fracture initiation mechanisms during hydraulic fracturing," Petroleum Science, vol. 8, no. 1, pp. 87-92, 2011.

[8] F. Zhang, G. Ma, X. Liu, Y. Tao, D. Feng, and R. Li, "Experimental analysis of multiple factors on hydraulic fracturing in coalbed methane reservoirs," PLoS One, vol. 13, Article ID e0195363, 2018.

[9] X. Lei, S. Zhang, G. Xu, and Y. Zou, "Impact of perforation on hydraulic fracture initiation and extension in tight natural gas reservoirs," Energy Technology, vol. 3, no. 6, pp. 618-624, 2015.

[10] P. C. Papanastasiou, "A coupled elastoplastic hydraulic fracturing model," International Journal of Rock Mechanics and Mining Science \& Geomechanics Abstracts, vol. 34, 1997. 
[11] J. Adachi, E. Siebrits, A. Peirce, and J. Desroches, "Computer simulation of hydraulic fractures," International Journal of Rock Mechanics and Mining Sciences, vol. 44, no. 5, pp. 739-757, 2007.

[12] J. Hu, J. X. Cao, X. Y. He, Q. F. Wang, and B. Xu, "Numerical simulation of fault activity owing to hydraulic fracturing," Applied Geophysics, vol. 15, no. 3-4, pp. 367-381, 2018.

[13] S. Zhang and S. Yin, "Determination of in situ stresses and elastic parameters from hydraulic fracturing tests by geomechanics modeling and soft computing," Journal of Petroleum Science and Engineering, vol. 124, pp. 484-492, 2014.

[14] Y. Xue, F. Gao, Y. Gao, X. Liang, Z. Zhang, and Y. Xing, "Thermo-hydro-mechanical coupled mathematical model for controlling the pre-mining coal seam gas extraction with slotted boreholes," International Journal of Mining Science and Technology, vol. 27, no. 3, pp. 473-479, 2017.

[15] S. Li, C. Fan, J. Han, M. Luo, Z. Yang, and H. Bi, "A fully coupled thermal-hydraulic-mechanical model with two-phase flow for coalbed methane extraction," Journal of Natural Gas Science and Engineering, vol. 33, pp. 324-336, 2016.

[16] Q. Liu, Y. Cheng, H. Zhou, P. Guo, F. An, and H. Chen, "A mathematical model of coupled gas flow and coal deformation with gas diffusion and klinkenberg effects," Rock Mechanics and Rock Engineering, vol. 48, no. 3, pp. 1163-1180, 2015.

[17] Y. Fan, C. Deng, X. Zhang, F. Li, X. Wang, and L. Qiao, "Numerical study of $\mathrm{CO}_{2}$-enhanced coalbed methane recovery," International Journal of Greenhouse Gas Control, vol. 76, pp. 12-23, 2018.

[18] Y. Mu, Y. Fan, J. Wang, and N. Fan, "Numerical study on injection of flue gas as a heat carrier into coal reservoir to enhance CBM recovery," Journal of Natural Gas Science and Engineering, vol. 72, 2019.

[19] T. Xia, F. Zhou, F. Gao, J. Kang, J. Liu, and J. Wang, "Simulation of coal self-heating processes in underground methane-rich coal seams," International Journal of Coal Geology, vol. 141-142, pp. 1-12, 2015.

[20] J. Zhao, D. Tang, H. Xu, Y. Meng, Y. Lv, and S. Tao, "A dynamic prediction model for gas-water effective permeability in unsaturated coalbed methane reservoirs based on production data," Journal of Natural Gas Science and Engineering, vol. 21, pp. 496-506, 2014.

[21] Q. X. Meng, W. Y. Xu, H. L. Wang, X. Y. Zhuang, W. C. Xie, and T. Rabczuk, "DigiSim-an open source software package for heterogeneous material modeling based on digital image processing," Advances in Engineering Software, vol. 148, Article ID 102836, 2020.

[22] Q. Wang, Z. Jiang, B. Jiang, H. Gao, Y. Huang, and P. Zhang, "Research on an automatic roadway formation method in deep mining areas by roof cutting with high-strength boltgrouting," International Journal of Rock Mechanics and Mining Sciences, vol. 128, Article ID 104264, 2020.

[23] F. Wu, H. Zhang, Q. Zou, C. Li, J. Chen, and R. Gao, "Viscoelastic-plastic damage creep model for salt rock based on fractional derivative theory," Mechanics of Materials, vol. 150, Article ID 103600, 2020.

[24] Y. Wang, W. K. Feng, R. L. Hu, and C. H. Li, "Fracture evolution and energy characteristics during marble failure under triaxial fatigue cyclic and confining pressure unloading (FC-CPU) conditions," Rock Mechanics and Rock Engineering, vol. 54, no. 2, pp. 799-818, 2021.

[25] C. Zhu, M. He, M. Karakus, X. Zhang, and Z. Tao, "Numerical simulations of the failure process of anaclinal slope physical model and control mechanism of negative Poisson's ratio cable," Bulletin of Engineering Geology and the Environment, vol. 80 , no. 4 , pp. $3365-3380,2021$.

[26] C. Zhu, M. C He, M. Karakus, X. Zhang, Z. Guo, and Z. Guo, "The collision experiment between rolling stones of different shapes and protective cushion in open-pit mines," Journal of Mountain Science, vol. 18, no. 5, pp. 1391-1403, 2021.

[27] Y. Liu, F. Wang, H. Tang, and S. Liang, "Well type and pattern optimization method based on fine numerical simulation in coal-bed methane reservoir," Environmental Earth Sciences, vol. 73, no. 10, pp. 5877-5890, 2015.

[28] W. C. Zhu, C. H. Wei, J. Liu, H. Y. Qu, and D. Elsworth, "A model of coal-gas interaction under variable temperatures," International Journal of Coal Geology, vol. 86, no. 2-3, pp. 213-221, 2011.

[29] X. Kong, E. Wang, Q. Liu et al., "Dynamic permeability and porosity evolution of coal seam rich in CBM based on the flow-solid coupling theory," Journal of Natural Gas Science and Engineering, vol. 40, pp. 61-71, 2017.

[30] L. D. Connell, "Coupled flow and geomechanical processes during gas production from coal seams," International Journal of Coal Geology, vol. 79, no. 1-2, pp. 18-28, 2009. 